\title{
Rekayasa Komposisi Pakan Pellet Benih Ikan Patin (Pangasianodon hypophtalmus) dengan Fermentasi Em4 (Effective microorganisms 4)
}

\author{
${ }^{*}$ Syahrizal, ${ }^{1}$ Zainal Arifin dan ${ }^{2}$ Paimung \\ ${ }^{1}$ Program Studi Budidaya Perairan, Fakultas Pertanian, Universitas Batanghari Jambi \\ ${ }^{2}$ Alumni Program Studi Budidaya Perairan, Fakultas Pertanian, Universitas Batanghari Jambi \\ Jalan Slamet Riyadi, Broni, Jambi 36122, Telp. +62074160103 \\ *1e-mail korenspodensi: syahrizal@ unbari.ac.id
}

\begin{abstract}
The high level feed of consumption of catfish (Pangasianodon hypopthalmus) is due to its relatively fast growth. Efforts to overcome the need for large and high quality feeds are needed to improve feed engineering through the administration of Effective Microorganisms 4 (EM4) bacteria in the hope that the protein in the pellet can increase and the texture is improved so that fish digestibility increases. The study design used was a complete randomized design (CRD) 4 (four) treatments 3 (tree) replications with ANOVA analysis. Catfish weighing $5 \pm 0.3$ grams / head with a length of $8 \pm 0.5 \mathrm{~cm}$ are fed commercially plled fermented for two days $0.5 \mathrm{ml}$ EM4 $/ 50 \mathrm{ml}$ water. $1.0 \mathrm{ml}$ and $1.5 \mathrm{ml}$ per kilogram of feed with protein values P0 $35.1282 \%, P 1$ $32.8506 \%, P 2$ 27.5527\%, and P3 32.3208\%. The experimental results showed that absolute growth were respectively P0 2.1 grams, P1 2.3 grams, P2 1.9 grams and P3 2.1 grams and absolute length $P 01.8 \mathrm{~cm}, P 11.8 \mathrm{~cm} \mathrm{~cm}, P 21.5 \mathrm{~cm}$ and $P 31.7 \mathrm{~cm}$. Graduation of live fish until observation day 20 amounted to $100 \%$ then entered day 30 PO 93.33\%, P1 93.33\%, P2 83.33\% and P3 90.00\%. Conversion of feed PO 1.3, P1 1.0,P2 1.2 and P3 1.1\%. Normal fish water quality Temperature 27.0 - 27.2o C, pH 6.0-6.7, DO2 5.0-5.3 mg// l, CO2 2.1-2.5 mg/and Ammonia 0.010-0.014 mg/l.
\end{abstract}

Keywords : catfish, feed and microorganisms

\begin{abstract}
Abstrak. Tingkat kosumsi pakan ikan patin (Pangasianodon hypopthalmus) yang tinggi disebabkan oleh pertumbuhannya yang relatif cepat. Upaya untuk memperoleh mengatasi kebutuhan pakan yang besar dan bermutu diperlukan rekayasa perbaikan pakan melalaui pemberian bakteri Effective Microorganisms 4 (EM4) dengan harapan protein pada pellet dapat menigkat dan teksturnya lebih membaik sehingga kecernaan ikan meningkat. Rancangan peneltian yang digunakan adalah rancangan acak lengkap (RAL) 4 (empat) perlakuan 3 (tiga) ulanagan dengan analisis Anova. Ikan patin ukuran bobot $5 \pm 0.3$ gram/ekor dengan ukuran panjang $8 \pm 0.5 \mathrm{~cm}$ diberi pakan komersial pellet difermentasi dua hari $0.5 \mathrm{ml}$ EM4 $/ 50 \mathrm{ml}$ air. $1.0 \mathrm{ml}$ dan $1.5 \mathrm{ml}$ per kilogram pakan dengan nilai protein P0 35.1282\%, P1 32.8506 \%, P2 27.5527\%, dan P3 32.3208\%. Hasil percobaan menunjukan bahwa pertumbuhan mutlak berturut-turut PO 2.1 gram, P1 2.3 gram, P2 1.9 gram daan P3 2.1 gram dan panjang mutlak PO $1.8 \mathrm{~cm}$, P2 $1.8 \mathrm{~cm}$, P2 $1.5 \mathrm{~cm}$ dan P3 $1.7 \mathrm{~cm}$. Kelulusan hidup ikan sampai pengamatan hari ke 20 berjumlah $100 \%$ kemudian memasuki hari 30 P0 93.33\%, P1 93.33\%, P2 83.33\% dan P3 90.00\%. Konversi pakan P0 1.3 , P1 1.0 P2 1.2 dan P3 $1.1 \%$. Kualitas air ikan peliharaan optimal suhu $27,0-27,2^{\circ} \mathrm{C}, \mathrm{pH}$ 6.0-6.7, $\mathrm{DO}_{2}$ 5,0-5,3 mg/l, $\mathrm{CO}_{2}$ 2,1-2,5 mg/l dan Amoniak 0,010-0,014 mg/l.
\end{abstract}

Kata Kunci : Ikan Patin, Pakan dan Microorganisme.

\section{PENDAHULUAN}

Hasil perairan berupa ikan merupakan katagori pangan yang bermutu karena ikan diketahui unsur gizi berupa protein dan lemak yang esensial sebagai keperluan fungsi fisiologis yang dibutuhkan bagi tubuh manusia. Pada saat ini kesadaran masyarakat mencari pangan bermutu semakin terasa dalm oreantasi kesehatan, peningkatan kecerdasan dan memperbaiki tingkat stunting. Dalam menghadapi permintaan pasar komuditas ikan yang besar, petani ikan berusaha mencari berbagai alternatif meningkatakan produksi produksi.

Komuditas ikan patin merupakan ikan unggulan dan primadona bagi pembudidaya ikan air tawar di Propinsi Jambi. Hal ini karena pertumbuhan ikan ini yang cepat. Tidak bertulang halus, rasanya yang khas dan harga relatife baik. Syahrizal dan Arifin (2017) ikan patin (Pangasianodon hypopthalmus) merupakan salah satu komuditas perikanan dalam program percepatan industrilisasi dari jenis komuditas perikanan budidaya di provinsi Jambi dengan jumlah produksi pada tahun 2012 sebesar 651.000 ton. Ikan patin ini dipelihara khususnya oleh masyarakat Jambi diperairan darat seperti pada kolam-kolam dan yang dominan dibudidayakan dalam keramba-keramba, jarring apung di sepanjang sungai Batanghari.

Ikan patin adalah jenis ikan termasuk yang rakus mengkonsumsi pakan. Ikan patin ini dikelompokkan pada ikan omnivore yakni pemakan jenis tumbuhan dan hewan. Tingkat kosumsi yang tinggi disebabkan oleh pertumbuhannya yang relative cepat dibandingkan dengan ikan beliharaan air tawar lainnya seperti ikan kan nila, mas dan ikan gurami. Dalam upaya untuk memperbaiki mutu dan efesiensi pemberian pakan pada ikan patin. dilakukan rekayasa perbaikan pakan. melalui pakan pellet diberi asupan minkroba dari Em4 dengan teknik perlakuan tersebut diharapkan dapat mengoptimalkan produksi ikan patin. Rekayasa pakan ini dilakukan karena sulit dan mahal mendapatkan protein dalam bahan baku untuk pakan ikan. Unsur protein mempunyai nilai jual yang tinggi bila dibandingkan unsur gizi lainnya seperti karbohidrta dan lemak. Kekurangan protein dalam tubuh ikan 
menyebabkan proses metabolisme fisiologi abnormal terganggu. pertubuhan tidak optimal dan kesehatan ikan terganggu kemungkinan kecernaan ikan yang belum baik dan efisien.

Rekayasa pellet yang di fermentasi dengan pemberian peberian Effetive Microorganisms 4 (EM4) dengan harapan terjadi perobahan komposisi terutama unsur organic berupa asam-asam amino (protein) protein dalam pakan yang dapat digunakan secara efesien oleh tubuh dan akan optimal meningkatkan pertumbuhan ikan patin, kesehatannya, serta dapat memperbaiki kelulusan hidup.

\section{METODOLOGI PENELITIAN}

Bentuk metode yang digunakan pada penelitian ini adalah metode dengan menggunakan rancangan acak lengkap (RAL) satu faktor dengan 4 tahap perlakuan. Untk pemperkcil bias dilakukan rancangan dengan 3 (tiga) kali ulangan dilakukan 3 kali ulangan, dengan memakai 12 unit wadah aquarium. Data yang didapat selama melakukan penelitian ditabulasi dalam bentuk tabel, kemudian akan dianalisis dengan analiisis statistic analisis sidik ragam ANOVA, dan uji Duncan (DNMRT) pada taraf 5\%. Adapun perlakuan yang akan digunakan sebagai berikut :

A. Pellet Komersial tidak difermentasi (Kontrol)

B. Pellet Komersial dengan Fermentasi EM4 $0.5 \mathrm{ml} / 50 \mathrm{ml}$ air. $/ \mathrm{kg}$ pakan

C. Pellet Komersial dengan Fermentasi EM4 $1.0 \mathrm{ml} / 50 \mathrm{ml}$ air. $/ \mathrm{kg}$ pakan

D. Pellet Komersial dengan Fermentasi EM4 $1.5 \mathrm{ml} / 50 \mathrm{ml}$ air/kg pakan.

Model percobaan yang dipakai dalam penelitian ini adalah model rancangan Stell and Terry (1991) yaitu :

Model linier : $Y i j=\mu+\tau i+\varepsilon i j$

Keterangan :

i : ulangan 1,2

Yijk : nilai pengamatan pada perlakuan ke-i dan ulangan ke-j

$\mu \quad$ : rataan umum

$\tau$ i : pengaruh perlakukan ke-i

eij : pengaruh acak pada perlakuan ke-I dan pengaruh acak pada perlakuan ke-i dan ulangan ke-j

Ikan percobaan yang digunakan merupakan ikan jenis patin siam (Pangasianodon hypophtalmus). Banyaknyaknya ikan yang diperlukan dalam percobaan ini yaitu sebanayak 120 ekor utuk padat tebar 10 ekor per wadah akuarium dengan bobot $5 \pm 0.3$ gram/ekor dan ukuran panjang $8 \pm 0.5 \mathrm{~cm}$.

Wadah yang digunakan untuk pemeliharaan berupa akuarium dengan ukuran $(60 \times 40 \times 50 \mathrm{~cm})$ berjumlah 12 unit. Kemudian akuarium di cuci terlebih dahulu. di keringkan selanjutnya diisi air yang telah diendapkan sejumlah 20 liter dengan padat tebar ikan uji 1 ekor/0.5 liter.

Bentuk pakan yang diberikan pada ikan percobaan adalah pakan komersial pellet denga kadar protein $40 \%$ dengan ukuran $\pm 1.5 \mathrm{~mm}$ yang diproksimat seperti pada tabel 1 . Pakan tersebut difermentasi selama 2 hari dengan dosis perlakuan P1. P2 dan P3 berturut-turut $0.5 \mathrm{ml} \mathrm{EM4/50} \mathrm{ml} \mathrm{air.} 1.0 \mathrm{ml} \mathrm{EM4/50} \mathrm{ml} \mathrm{air.} \mathrm{dan} 1.5 \mathrm{ml}$ EM4/50 ml air yang akan diberikan untuk satu kilo pakan dengan teknik penyemprotan secara rata. Hasil proksimat pakan diberikan pada ikan uji dapat dilihat pada tabel 1.

Tabel 1. Hasil Proksimat Pakan Komersial Protein 40\% Dan Pakan Yang Difermentasi Dengan EM4 Selama Dua Hari

\begin{tabular}{ccccccc}
\hline No. & Kode Sampel & Bahan Kering $(\%)$ & Kadar Abu $(\%)$ & Lemak $(\%)$ & Protein $(\%)$ & Serat $(\%)$ \\
\hline 1 & P0 & 92.8159 & 10.7828 & 4.7971 & 35.1282 & 0.6150 \\
2 & P1 & 71.8038 & 10.6945 & 4.9607 & 32.8506 & 1.5300 \\
3 & P2 & 73.5643 & 10.7161 & 3.9538 & 27.5527 & 2.0400 \\
4 & P3 & 68.9645 & 10.4385 & 3.3869 & 32.3208 & 1.2850 \\
\hline
\end{tabular}

Sumber : Laboratorium Perternakan Unja 2019

Bahan fermentasi digunakan adalah bahan Effective Microorganisme 4 (EM4) yang mengandung microorganisms. Lactobacillus casei $20 \times 10^{6} \mathrm{sel} / \mathrm{ml}$ dan Saccharomyces cereiviae $35 \times 10^{5} \mathrm{sel} / \mathrm{ml}$ dan lama fermentasi 3 (tiga) hari.

Sebelum dilakukan percobaan, ikan di aklimatisasi 3 selama 3 (tiga) hari. Kemudian ikan dimasukan kedalam masing-masing wadah percobaan yang telah diacak. Pemberian pakan diberikan secara kenyang pagi (08.00 wib), siang (13.00 wib) dan sore (17.00 wib). Kotoran berupa sisa pakan pises akan disifon setiap pagi hari sebelum diberi pakan dengan pengantian air 30\% dan pengantian air secara total secara berkala dilakukan dalam 10 hari.

Observasi dan monitoring kualitas air dilakukan pada awal, petengan dan dan akhir percobaan. Sebagian variable kualitas air diobsevasi dan dimitoring dilokasi percobaan seperti suhu dan $\mathrm{pH}$. faktor kualitas air lainya akan 
Syahrizal, Zaenal Arifin, dan Paimung. Rekayasa Komposisi Pakan Pellet Benih Ikan Patin (Pangasianodon hypophtalmus) dengan Fermentasi Em4 (Effective microorganisms 4)

diambil dalam bentuk sampel guna diperiksa di laboratorium niversitas Batanghari Fakultas pertanian Unbari. berupa $\mathrm{NH}_{3}$. $\mathrm{O}_{2}$ terlarut dan $\mathrm{CO}_{2}$.

Pengamatan terhadap tingakat pertumbuhan bobot dilakukan setiap 10 hari hari rumus $. \mathrm{W}_{\mathrm{m}}=\mathrm{W}_{\mathrm{t}}-\mathrm{W}_{0}$ dan $\mathrm{P}_{\mathrm{m}}=\mathrm{P}_{\mathrm{t}}-\mathrm{P}_{0}$. Perhitungan pertumbuhan didasarkan atas bobot biomas ikan pada awal dan 10 hari kemudian selama 30 hari. Sedang panjang ikan berdasarakan sampel. Pengamatan kelangsunga hidup ikan percobaan (Survival Rate/SR) digunakan rumus Goddard (1996) :

$S R=\frac{\text { Jumlah ikan yang mati }}{\text { Jumlah ikan yang hidup }} \times 100 \%$

Keterangan : SR = Survival Rate (Kelangsungan hidup)

Selama percobaan. Pada pengamatan konversi pakan dilakukan dengan menggunakan cara menimbang pakan awal kemudian ditimbang pakan akhir pada masing-masing perlakuan dan diaplikasikan dalam rumus konversi ratio (FCR) menurut Goddard (1996) rumus :

$F C R=\frac{F}{(W t+W d)-W o}$

Keterangan : FCR $=$ Koversi pakan

$\mathrm{Wt}=$ Biomas total ikan pada akhir pemeliharaan (gram)

$\mathrm{Wo}=$ Biomas total ikan pada awal pemeliharaan (gram)

$\mathrm{Wd}=$ Bimas itotal total ikan yang mati selama pemeliharaan (gram)

$\mathrm{F}=$ Jumlah pakan yang habis selama pemeliharaan (gram)

Pertumbuhan Ikan Patin

\section{HASIL DAN PEMBAHASAN}

Pertumbuhan rataan ikan patin siam (Pangasianodon hypophtalmus) percobaan dalam waktu 30 hari pemeliharaan dapat di lihat pada gambar 1 data gerafik di bawah sebagai berikut ini :

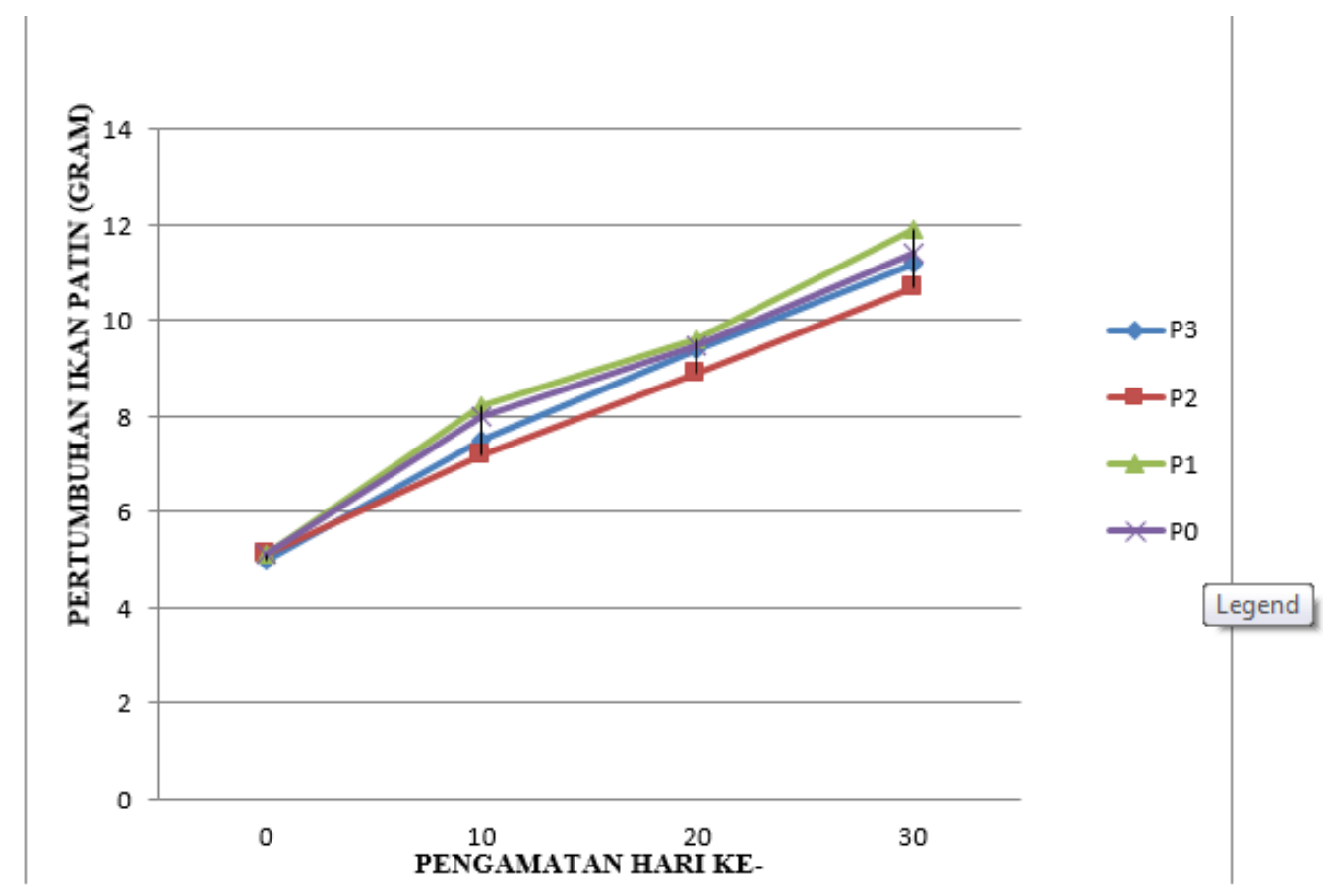

Gambar 1. Pertumbuhan Rataan (Gram) Ikan Patin (Pangasianodon hypothalamus) Percobaan Selama Penelitian.

Tingkat pertumbuhan ikan patin siam (Pangasianodon hypopthalmus) dari permulaan percobaan hingga samapai hari 30 dapat dilihat seperti pada gambar 1 yang memperlihatkan pola pola pertumbuhan ikan patin 
percobaan meningkat secara linier. Bentuk trend pola pertumbuhan yang linier tersebut menggambarkan bahwa selama percobaan ikan uji tumbuh terus menerus dan tidak terhenti dan dan ikan ikan terus menerus pula mendapatakan makakanan. Menurut Huet (dalam Tahapari, Ariyanto dan Gunadi, 2008) menjelaskan bahwa pertumbuhan ikan akan terjadi bila jumlah pakan yang dikosumsi lebih besar dari yang dibutuhkanb untuk memelihara tubuh. Pertambahan bobot dan panjang (pertumbuhan mutlak) ikan patin rataan 0,37 gram/ekor dan panjang 2-3 cm/ekor dalam kolam dipupuk, diperoleh pertumbuhan terbaik dengan penambahan pakan pellet $15 \%$ dengan kadar protein 40\%, kadar air 11\%, lemak 6\% dan serat kasar 3\% selama 6 minggu yaitu 39,17 $\pm 1,39$ gram dan 11,15 $\pm 0,09 \mathrm{~cm}$ (Tahapari, Ariyanto dan Gunadi, 2008)

Sedangkan pertumbuhan bobot mutlak rataan ikan patin (Pangasianodon hypopthalmus) selama percobaan dapat dilihat pada tabel 2, sebagai berikut:

Tabel 2. Pertumbuhan Rataan Bobot Mutlak Ikan Patin (Pangasianodon hypopthalmus) Percobaan Selama Penelitian.

\begin{tabular}{ccc}
\hline Perlakuan & Rataan (gram) & Notasi \\
\hline P0 & 2.1 & a \\
P1 & 2.3 & a \\
P2 & 1.9 & a \\
P3 & 2.1 & a \\
Total & 8.4 & \\
Rata-Rata & 2.1 & \\
\hline
\end{tabular}

Rataan pertumbuhan panjang mutlak ikan patin siam (Pangasianodon hypopthalmus) dengan pemberian pakan pellet komersial yang difermentasi dengan EM4 dapat dilihat pada tabel 3 berikut ini.

Table 3. Pertumbuhan Rataan Panjang Mutlak Ikan Patin (Pangasianodon hypopthalmus) Percobaan Selama Penelitian.

\begin{tabular}{ccc}
\hline Perlakuan & Rataan $(\mathrm{cm})$ & Notasi \\
\hline P0 & 1.8 & a \\
P1 & 1.8 & a \\
P2 & 1.5 & a \\
P3 & 1.7 & a \\
Total & 6.8 & \\
Rata-Rata & 1.7 & \\
\hline
\end{tabular}

Pada tabel 2 dan 3 rataan pertambahan bobot dan panjang (pertumbuhan mutlak) ikan patin (Pangasianodon hyopopthalamus) dengan pemberian makanan yang di frementasi memakai EM4 menggambarakan perbedaan yang tidak signifikan $(\mathrm{P}>5 \%)$ untuk seluruh perlakuan. Pada bahan pakan yang di fermentasi (P1,P2 dan P3) berpagruh sedikit lebih baik terhadap pertumbuhan. hal ini diduga karena penambahan EM4 menyebabkan tekstur pada pakan kebih lembut dan mudah dicerna serta aroma pada pakan yang terfermentasi menjadi daya tarik bagi ikan untuk mengkonsumsinya. Menurut Dewi dan Tahapari (2017) bahwa fermentasi pakan yang dilakukan dengan cara mencampurkan $10 \mathrm{ml}$ probiotik dengan $200 \mathrm{ml}$ air disemprotkan dengan menggunakan sprayer untuk $1 \mathrm{~kg}$ pakan ikan lele dengan kadar protein 28\%-30\% yang dibiarakan selama selama dua hari menghasilkan pakan yang lebih bertekstur lebih empuk, berbau seperti tape, dan warna putih karena ditumbuhi jamur dengan feeding rite 3-5\% dari biomassa perhari. Pada awal tebar, pakan diberikanan sebanayak 5\% waktu 10 hari pertama, $4 \%$ pada 10 hari kedua, 3\% pada 10 hari ketiga hingga pemanenan. Bobot ikan yang di pelihara selama 35 harii adalah bobot awal $20.7 \pm 0.9$ gram/ekor dan $20.7 \pm 1.9$ gram/ekor menjadi berat akhir $76.9 \pm 0.2$ gram/ekor dan kotrol $74.2 \pm 0.2$ gram/ekor. Pertumbuhan ikan lele percobaan yang diberi pakan difermentasi lebih baik dari control.

Pertumbuhan yang baik pada perlakuan P1 dengan dosis EM4 $0.5 \mathrm{ml} / 50 \mathrm{ml}$ per kilogram pakan dalam percobaan ini diduga selain oleh nilai energi yang tinggi disebabakan oleh lemak pakannya yang diikuti kandungan kadar protein juga relatif tinggi. Suhenda, Setijaningsih dan Suryanti (2005) protein meruapakan zat makanan yang dibutuhkan untuk memelihara fisiologis tubuh, pembentukan jaringan, penggantian jaringan tubuh yang rusak, serta penambahan asam amino protein tubuh dalam proses pertumbuhan. Protein juga dapat dipakai sebagai sebaga sumber energy. Mengingat haraga protein relative lebih nahal dibandingkan dengan karbohidrat dan lemak, maka protein diupayakan sebahagian besar dimanfaatkanan untuk pertumbuhan dan penggantian jaringan yang rusak (Lovel, 1988). Selanjutnya Haver at al. (1973) menjelaskan bahwa protein merupakan bagian terbesar dari daging 
ikan. Oelh karena itu dalam menentukan kebutuhan nutrient, kebutuhan protein perlu dipenuhi terlebih dahulu. Pemanfaatan protein bagi tingkat pertumbuhan ikan dipengaruhi oleh beberapa faktor anatara lain ukuran ikan, umur ikan, kualitas protein, energi pakan, suhu air dan tingkat pemberian pakan (NRC, 1983). Untuk pemeliharaan ikan harus diupayakan pemberian sejumlah protein yang cukup secara terus menerus sehingga makanan tersebeut dapat diubah menjadi protein tubuh secara efesien (NRC, 1977). Salah satu tujuan budidaya ikan adalah untuk produksi ikan sebesar mungkin dalam waktu singkat, dan hal ini dapat dicapai dengan mempercepat pertumbuhan ikan (Stickney, 1979)).

\section{Kelangsungan Hidup (SR)}

Hasil pengamatan dan analisis tingkat kelangsungan hidup ikan patin siam (Pangasianodon hypopthalmus) selama peneltian dapat dilihat pada Gambar 2. Pengamatan kelangsungan hidup ikan patin yang diberi pakan di fermentasi dengan EM4 tersebut selama 30 hari persentase rataan tingkat kelangsungan hidup benih ikan patin dapat pada grafik berikut ini :

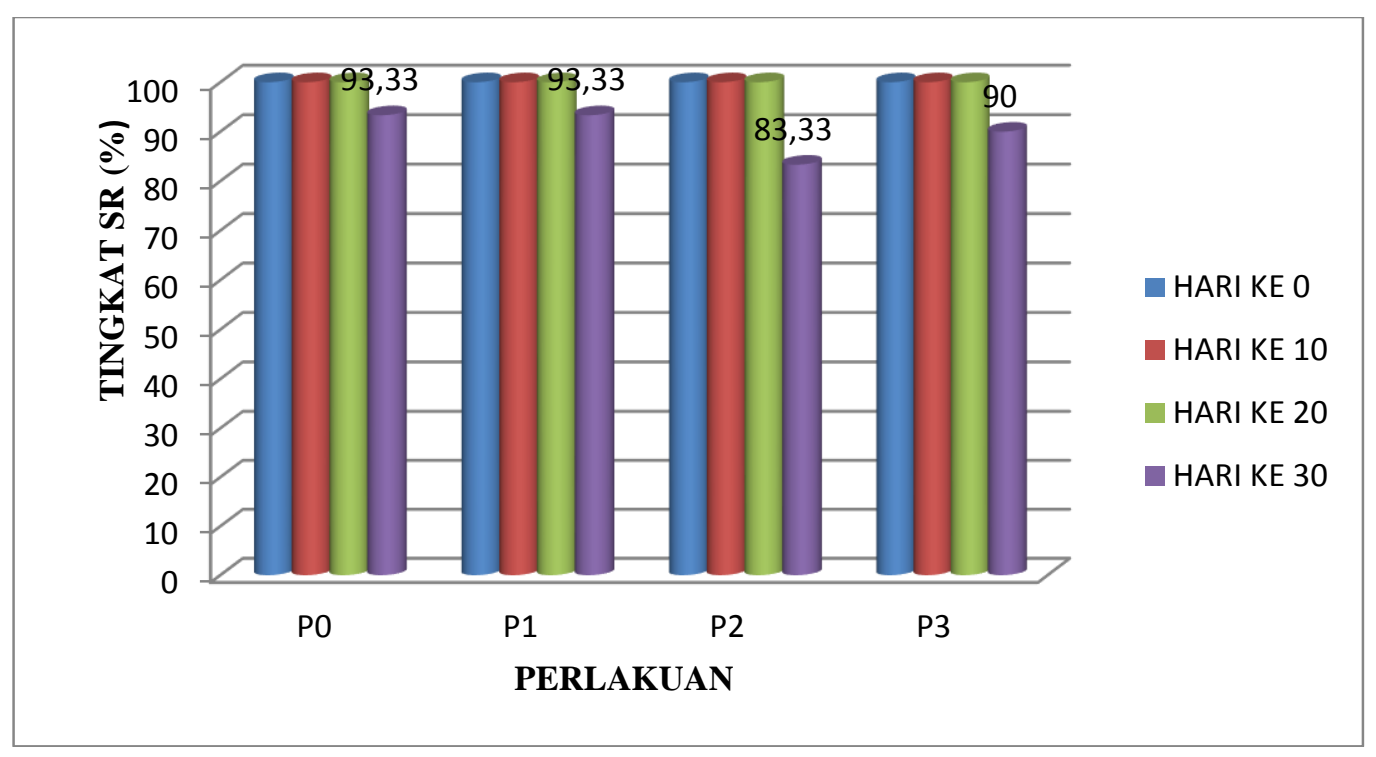

Gambar 2. Grafik Kelangsungan Hidup Ikan Patin (Pangasianodon hypophtalmus) Percobaan Selama Peneltian

Grafik diatas menunjukan bahwa rataan kelangsungan hidup ikan patin (Pangasianodon hypopthalmus) dengan pemberian semua bahan pakan percobaan yang difermentasi EM4 menunjukan tidak berbeda nyata $(\mathrm{P}>5 \%)$. Tingkat kematian ikan secara keseluruhan berada pada taraf kematian diatas $80 \%$. hanya hari ke 30, sedangkan sebelumnya kelangsungan hidup $100 \%$ hal ini diperkirakan kekebalan tubuh ikan atau imunitas ikan percobaan relatif baik pada awal sampai hari ke 20 percobaan, kemudian mengalami penurunan. Tingginya tingkat kekebalan tubuh ikan atau imunitas ikan percobaan disebabkan asopan gizi yang cukup dan seimbang. Menurut Effendi (2003) tingkat kelangsungan hidup benih ikan patin sampai umur dua bulan pemeliharaan bisa mencapai 70 sampai $90 \%$. Kematian benih ikan ikan patin umumnya disebabkan oleh kualitas air yang tidak optimal. Kematian benih ikan patin umumnya disebabkan oleh kualitas air yang tidak baik. Menurut Septimesy, Jubaedah. dan Sasanti (2016) padat tebar 20 dengan ukuran $3 \pm 0.5 \mathrm{~cm}$ kelangsungan hidup selama pemeliharaan sebesar $73.33 \pm 4.30 \%$. Savitri. A. Q. Hasani dan Tarsim (2015) menjelaskan bahwa kalansungan hidup ikan patin dipelihara 30 hari adalah $60-88 \%$ pada FR 5\% pada sistem bioflok dengan FR 1\%. Menurut Bokings. Koniyo dan Juliana (2017) kelangsungan hidup benih ikan patin siam dipelihara 5 minggu dengan padat tebar 2 ekor/ liter yang diberi pellet dan kombinasi cacing sutra adalah sebesar $69.05 \%-95.24 \%$.

\section{Konversi Pakan}

Konversi pakan yang dimakan oleh ikan patin (Pangasianodon hypophtalmus) selama penelitian dapat dilihat pada tabel 4 sebagai berikut : 
Syahrizal, Zaenal Arifin, dan Paimung. Rekayasa Komposisi Pakan Pellet Benih Ikan Patin (Pangasianodon hypophtalmus) dengan Fermentasi Em4 (Effective microorganisms 4)

Tabel 4. Koversi Pakan Ikan Patin (Pangasianodon hypophtalmus) Percobaan Selama Penelitian

\begin{tabular}{ccc}
\hline Perlakuan & Rataan & Notasi \\
\hline P0 & 1.3 & $\mathrm{~b}$ \\
P1 & 1.0 & $\mathrm{a}$ \\
P2 & 1.2 & $\mathrm{a}$ \\
P3 & 1.1 & $\mathrm{a}$ \\
Total & 4.6 & \\
Rataan & 1.1 & \\
\hline
\end{tabular}

Dari table diatas menunjukan nilai rataan efesiensi pakan berbeda signifikan antar perlakuan $(\mathrm{P}>0,5 \%)$ yang tertinggi pada perlakuan P0 dan P3, kemudian diikuti pakan P2 dan terendah pada P1. Hal ini memperlihatakan bahwa konversi terbaik pada P1 dan diikuti P2 dan P3 diduga gejala ini karena pakan P1 paling baik dan jumlah koisumsi pakan paling tinggi. Djarijah (1995) menjelaskan bahwa pakan ikan yang mempunyai kualitas baik baik nilai konversinya rendah, sebaiknya pakan yang punya kualitas baik nilai konversinya tinggi. Widastuti at al (2010) menjelaskan bahwa semakin kecil nilai konversi pakan semakin baik mutu pakan yang diberikan. Nilai konversi kurang dari 3 masih dianggab masih dianggab efesien. Nilai konversi pakan ikan antara 1.5-1.8 dan dilakukan cukup efesien pada konversi 1.7 (Mudjiman, 1998)

\section{Kualiats Air}

Parameter kualitas dalam akuarium percobaan setiap perlakuan selama penelitian dapat dilihat pada tabel 5 di berikut ini.

Tabel 5. Hasil Pengamatan Parameter Kualaitas Air Ikan Patin (Pangasianodon hypophtalmus) Percobaan Selama Penelitian

\begin{tabular}{|c|c|c|c|c|c|c|c|}
\hline \multirow{2}{*}{ No } & \multirow{2}{*}{ Parameter } & \multirow{2}{*}{ Satuan } & \multicolumn{4}{|c|}{ Hasil Pengujian } & \multirow{2}{*}{ Metode Pengukuran } \\
\hline & & & $\mathbf{A}$ & B & C & D & \\
\hline 1 & Suhu & ${ }^{\circ} \mathrm{C}$ & 27,0 & 27,1 & 27,1 & 27,2 & Thermometer \\
\hline 2 & $\mathrm{pH}$ & - & 6,5 & 6,7 & 6,2 & 6,0 & $\mathrm{pH}$ Meter \\
\hline 3 & DO & $\mathrm{mg} / \mathrm{L}$ & 5,0 & 5,3 & 5,1 & 5,0 & DO-Metri \\
\hline 4 & $\mathrm{CO}_{2}$ & $\mathrm{mg} / \mathrm{L}$ & 2,3 & 2,1 & 2,4 & 2,5 & $\mathrm{CO}_{2}$-test kit \\
\hline 5 & Ammonia & $\mathrm{Mg} / \mathrm{L}$ & 0,012 & 0,010 & 0,015 & 0,014 & SNI06-24791991 \\
\hline
\end{tabular}

Beberapa kualiatas air yang mempengaruhi kehidupan dan pertumbuhan ikan patin ikan. Suhu dapat mempengaruhi pertumbuhan, karena mempengaruhi selera dan metabolism makanan yang dimakan. Menurut Effendi (2003) perubahan suhu dari $3-4^{\circ} \mathrm{C}$ akan menyebabkan perubahan perubahan metabolism yang mengakibatakan kejutan suhu, meningkatakan toksisitas kontaminan yang terlarut, menurunkan DO yang menyebabkan meningkatakan kematian pada ikan. Kisaran suhu optimal bagi kehidupan ikan adalah $25^{\circ} \mathrm{C}-30^{\circ} \mathrm{C}$. Suhu yang ada pada perlakuan percobaan $27,{ }^{\circ} \mathrm{C}-27,2^{\circ} \mathrm{C}$.

Tingkat keasaman air percobaan $(\mathrm{pH})$ akan memepengaruhi laju pertumbuhan dan kelangsungan hidup ikan, $\mathrm{pH}$ yang diukur berkisar 6,0.- 6,7 ppm. Nila tersebut menunjukan kisaran yang relative baik bagi pertumbuhan dan kelangsungan hidup ikan patin. Menurut Boyd (1982) pH yang optimal bagi pertumbuhan sebagian besar spesies ikan berkisar anatar 6,5-9,0.

Nilai oksigen terlarut (DO) pemeliharaan ikan patin percobaan berkisar anatara 5,0 - 3,3 mg/L. Djariah (2001), kandungan DO yang cukup baik untuk kehidupan ikan patin berkisar 2-5 mg/L. Flutuasi kadar oksigen yang tinggi diperairan hingga mencapai yang sangat rendah berbahaya bagi organism akuatik.

Kadar kandungan karbodioksisa $\left(\mathrm{CO}_{2}\right)$ dalam media pemeliharaan selama dilakukan percobaan berkisar anatar 2,1mg/L-2,5 mg/L. Kandungan $\mathrm{CO}_{2}$ dalam dalam air untuk pemelihaaran ikan patin sudah cukup baik kurang dari $5 \mathrm{mg}$. Meskipun peranan CO2 sangat besar bagi organism akuatik, namun kandungan yang berlebihan sangat mengganggu, bahkan menjadi racun langsung bagi biota.

Kadar ammonia $\left(\mathrm{NH}_{3}\right)$ selama percobaan berkisar anatar 0,010 mg/L-0,014 mg/L. Tingkat kadar $\mathrm{NH}_{3}$ tersebut tergolong optimal, hal ini diduga meningkatnya bahan buangan metabolism dari ikan patin itu sendiri. Budiman (2010) menjelaskan bahwa kosentrasi ammonia yang ideal bagi ikan tidak lebih dari $1 \mathrm{mg} / \mathrm{L}$.Ikan tidak bisa bertoleransi terhadap kadar ammonia bebas yang terlalu tinggi karena dapat mengganggu proses pengikatan oksigen oleh darah (Effendi, 2003). Cholik dkk (1986). mengatakan bahwa kandungan ammonia yang tinggi juga dapat di sebabkan karena sekresi dan sisa pakan dalam air. ammonia merupakan senyawa beracun yang berasal dari buangan sisa metabolisme biota periran maupun dari sisa-sisa pakan. 


\section{KESIMPULAN}

Setelah melakukan percobaan, pengamatan dan analisis data dari penelitian ini, maka dapat diambil kesimpulan sebagai berikut :

1. Pemberian EM4 yang di fermentasi dalam pakan terhadap pertumbuhan mutlak benih ikan patin terbaik dengan kadar $0.5 \mathrm{ml} / 50 \mathrm{ml}$ air per kg pakan (P1) dengan kadar protein pakan 32.85\%, dengan konversi pakan 1.0.

2. Kelangsungan hidup ikan patin percobaan terbaik pada P0 (93.33\%) dan P1 (93.33\%) memasuki pada hari 30 .

3. Kualitas air dan pakan selama penelitian dapat mendukung terhadap pertumbuhan dan kelangsungan hidup benih ikan patin siam (Pangasianodon hypophtalmus).

\section{DAFTAR PUSTAKA}

Ahmad, R.Z.2005. Pemanfaatan Kamir, Sacharomyces cerevieae Untuk Ternak. Balai Penelitian Veteriner.Bogor.

Bokings. U. L. Y. Koniyo dan Juliana. 2017. Pertumbuhan Dan Kelangsungan Hidup Benih Ikan Patin Siam (Pangasianodon hypophthalmus) Yang Diberi Pakan Buatan. Cacing Sutra (Tubifex sp.) dan Kombinasi Keduanya NIKè. Jurnal Ilmiah Perikanan Dan Kelautan Fakultas Perikanan dan Ilmu Kelautan Universitas Negeri Gorontalo. Volume 5 Nomor 3 ISSN 2303-2200. Hal 82 -89.

Boyd, C.E. 1982. Water Quality Management for Pond Fish Culture. Elsevier Puplishing Company. New York. $318 \mathrm{p}$.

Budiman, 2010. Budidaya Ikan Air Tawar Dengan Sistem Keramba jarring Apung (KJA) Sumatra Selatan.

Cahyo P. 2015. Pemanfaatan Amapas Tahu Sebagai Pakan Ikan Budidaya Ikan Nilem Cikembul Kecamatan Pakucen Kabupaten Bayumas. Laporan Penelitian . Universitas Muhamaddiyah Purwakerto: Purwakerto.

Cholik, F, A.G Jagatraya, R.P Pernomo Dan A. Jauzi. 2005. Akuakulture Tumpuan Harapan Masa Depan Bangsa. Masyarakat Perikanan Nusantara dan Taman Akuarium Air Tawar Taman Mini Indonesia Indah. Jakarta. 415 Hal.

Dewi, R.S. dan E. Tahapari. 2017. Pemanfaatan Probiotik Komersial Pada Pembesaran Ikan Lele (Clarias gariepinus). Jurnal Riset Akuakultur. 12 (3), 2017, 275-281. P-ISSN 1907-6754; e-ISSN 25026534 with RISTEK DIKTI Accreditation.

Djariah, A.S 2001. Budidaya Ikan Patin. Kanisius Yoyakart 87 Hal.

Susanto, H dan Amri, K 2002. Budidaya Ikan Patin Penebar Swadaya. Jakarta 90 Hal.

Effendi, H, 2003. Telaah kualitas Air Bagi Pengelolaan Sumber Daya dan Lingkungan Perairan. Penerbit Kanasius. Yokyakarta.

Hernowo. 2001. Pembenihan Patin Skala Kecil Dan Besar. Solusi Permasalahan. Penebar Swadaya. Jakarta. 66 Hal.

Khairuman dan Khairul. 2008. Buku Pintar Budidaya Ikan kosumsi. Agromedia Pustaka. Jakarta.

Kordi, M.G.H. 2005. Budidaya Ikan patin. Pemenihandan Pembesaran. Yayasan Pustaka Nusanatara. Yokyakarata 170 Hal.

Mudjiman. A., 1998. Makanan Ikan. Cet-XI. Penebar Swadaya Bogor

Munisa. Q. Subandiyono. Pinandoyo. 2015. Pengaruh Kandungan Lemak Dan Energi Yang Berbeda Dalam Pakan Terhadap Pemanfaatan Pakan Dan Pertumbuhan Patin (Pangasianodon Pangasianodon). Journal of Aquaculture Management and Technology Volume 4. Nomor 3. Halaman 12-21 Online di : http://ejournals1.undip.ac.id/index.php/jamt

Putri.F.. Hasan Dan K.Haetami.2012. Pengaruh Pemberian Probiotik Pada Pellet Yang Mengandung Kaliandra (Caliandracalothyrsus) Terhadap Pertumbuhan Benih Ikan Nila. Jurnal Perikaan Dan Kelautan ISSN : 20088-3137.VOL.3. NO..4. :283-291.

Susanto, H Dan Amri, K. 2002. Budi Daya Ikan Patin. Penebar Swadaya. Jakarta. 90 Hal

Savitri. A. Q. Hasani dan Tarsim. 2015. Pertumbuhan Ikan Patin Siam (Pangasianodon hypopthalmus) Yang Dipelihara Dengan Sistem Bioflok Pada Feeding Rate Yang Berbeda. e-Jurnal Rekayasa dan Teknologi Budidaya Perairan. Vol. IV No 1. ISSN: 2302-3600.

Septimesy. A . D. Jubaedah dan A.D. Sasanti. (2016) Pertumbuhan Dan Kelangsungan Hidup Ikan Patin (Pangasianodon sp.) Di Sistem Resirkulasi Dengan Padat Tebar Berbeda. Jurnal Akuakultur Rawa Indonesia. 4(1) hal 1-8. ISSN : 2303-2960.

Sell. RG.P dan Terry 1991. Prinsip dan Prosedur Statistia : Suatu Pendekatan Biometrik. Gramedia Pustaka Utama. Jakarata.

Syahrizal, Syafratilofa dan A.M Sopiana. 2017. Urgensi Perbedaan Waktu Fermentasi Em4. (Effective Microorganisms) Pada Bahan Pakan Untuk Ikan Patin (Pangasianodon hypophtalmus) Jurnal Akuakultur Sungai dan Danau Vol. 3 No. 1. Hal. 1 - 11 ISSN Print 2503-4766 ISSN Online 2597-8837 
Syahrizal dan M. Y. Arifin. 2017. Analisis Kandungan Merkuri (Hg) Pada Air dan Daging Ikan Patin Siam (Pangasianodon hypopthalmus) Di KJA Danau Sipin Jambi. Jurnal Akuakultur Sungai dan Danau Vol. 2 No. 1 Tahun Hal. 9 - 17. ISSN Online 2503-4766

Stell. R.G.P. Dan Terry. J.H.1991. Prinsif Dan Prosedur Statistika : Suatu Pendekatan Biometrik .Gramedia Pustaka Utama.Jakarta.

Suhenda, N, L Setijaningsih dan Y. Suryanti. 2005. Pertumbuhan Benih ikan Patin Jambal (Pangasianodon djambal) Yang Diberipakan Dengan Kadar Protein Berbeda. Berila Biologi. Volume 7. Nomor 4. Balai Riset Perikanan Budidaya Air Tawar Jl.SempurNo. 1 Bogor Telp. (0251) 313200 e-mail: brpbat @, telkom.net

Tahapari, E., D. Ariyanto dan B.Gunadi. 2008. Optimasi Pemberian Pakan Buatan Pada Pendederan Ikan Patin (Pangasionodon hypohpthalmus) Di Kolam Yang Dipupuk. Jurnal Perikanan Universitas Gajah Mada (J. Fish. Sci.) X (1): 45-52. ISSN: 0853-6384. 